Proceedings of the 2018 International Scientific Conference 'Economic Sciences for Agribusiness and Rural Economy' No 2, Warsaw, 7-8 June 2018, pp. 347-352

\title{
THE ORGANISATION OF TRANSPORT IN THE AGRIBUSINESS SECTOR IN THE RESEARCH OF THE FACULTY OF ECONOMIC SCIENCES OF WULS-SGGW IN THE 21ST CENTURY
}

\author{
Tomasz Rokicki, $\mathrm{PhD}^{1}$ \\ Faculty of Economic Sciences, Warsaw University of Life Sciences - SGGW
}

\begin{abstract}
Transport is a very important branch of the economy. It was quite well recognized in the case of industry services, however, there have been few studies on transport services provided in the agribusiness sector. This gap was filled by employees of the Faculty of Economic Sciences at WULS-SGGW. The subjects of interest were entities dealing in food processing. The study reviewed research and publications of the Faculty's employees that were created in the 21 st century. The majority of enterprises did not have a separate department dealing with transport. Apart from own transportation, small and micro enterprises also combined their own and external transport means. Forwarding services were used to a small extent in the shipping process organisation. The results of the research at WULS-SGGW and other studies were quite similar.
\end{abstract}

Keywords: transport cost, agribusiness, food processing, own and external transport JEL codes: D22, L91, Q10, R40

\section{INTRODUCTION}

Transport is a very important sector, one of the most important factors of economic progress and an important tool of production (Lacny, 2009). A thriving economy depends on the efficient functioning of transport and logistics. On the other hand, the development of transport depends on economic growth and increasing trade exchange (Klepacki and Rokicki, 2008). It should be added that transport needs are continuously evolving and changing along with social and economic development (Rydzkowski and Wojewódzka-Król, 2009).

\section{THEORETIC BASES}

Transport is defined as a combination of activities consisting in the movement of tangible goods in space, using appropriate technical means (Baran et al., 2008). Within an enterprise, transport is an integral part of the company's logistic system. It enables the ensurance of deliveries of goods at the right time, in good condition and at an acceptable cost (Coyle, Bardi and Langley Jr, 2007). Transport management should be one of the fundamental activities within any enterprise or transport system (Kisperska-Moroń and Krzyżaniak, 2009).

${ }^{1}$ Corresponding author: Nowoursynowska 166, 02-787 Warsaw, Poland, tomasz_rokicki@sggw.pl, +4822 5934259 
Agribusiness, as a field of economic activity, is defined as a system of fostering the development of entrepreneurship. By applying necessary resources, an entrepreneur boosts the productive potential of a company by maximizing profit through their efficient use and adapts to changing market conditions. The majority of companies operating in the field of agribusiness are fragmented individual farms, and small and medium-sized companies using local resources. At the other end are agribusiness companies representing a rather industrial-style agriculture in the sense that these farms are often very large, highly specialized, and run like factories with a large input of fossil fuels, pesticides and other chemicals, and synthetic fertilizers derived from oil (Larsen, 2007). Agribusiness can also be defined as a system which creates the food production chain. In this situation companies are perceived as units creating the food supply chain in which transport is a very significant issue. The transport system in the company is a component of many elements (Fijałkowski, 2003; Lasek et al., 2008). In order to obtain an appropriate, well designed, effective and optimal level of transport, managers are obliged to treat it as an important, even fundamental activity in the production system (Rokicki, 2011).

\section{MATERIALS AND METHODS}

The article presents the most important results of research on transport in the agribusiness sector conducted at the Faculty of Economic Sciences at WULS-SGGW, in Warsaw. An analysis of articles and studies written by employees of the Faculty of Economic Sciences was used. Data for research concern the years 2000-2017. The work uses a descriptive, tabular and graphic method.

\section{RESULTS AND DISCUSSION}

Transport in agribusiness is a fairly new topic, undertaken in research at the Faculty of Economic Sciences at WULS-SGGW, in Warsaw. The first thorough research is related to the emergence of the field of study - logistics. The manual entitled 'Logistics. Selected issues' (Baran et al., 2008) is worth mention- ing here as it presents the organisation and conditions regarding logistics, including transport. Klepacki and Rokicki (2010), in the article entitled 'The situation and perspectives for the development of transport in Poland', described transport in Poland. Another important work was the publication of Rokicki and Wickiego (2010) entitled 'Transport and storage in agriculture as an element of logistics'. The authors referred to the rarely discussed problem of logistics on farms.

A breakthrough took place when the Faculty obtained a research grant entitled 'Logistic processes in the functioning of agri-food processing enterprises'. At that time, based on empirical research, a lot of studies were made. Only selected ones are presented in this study. All studies were based on a given number of enterprises. Enterprises were assigned to an industry in compliance with their declaration pursuant to their PKD (Polish Classification of Activity), whereas company size was determined based on the number of employees. The following enterprise sizes were distinguished according to number of employees: microbusinesses ( $0-9$ employees), small enterprises (10-49 employees), medium-sized enterprises (50-249 employees) and large enterprises (250 and more employees). Data used in the analysis come from surveys conducted from December 2009 until March 2010. Survey questionnaires were mailed to all enterprises of the agricultural and food production sector contained in the REGON database. Altogether there were 8,498 survey questionnaires. 508 questionnaires $(6 \%)$ were sent back. After rejecting questionnaires containing significant deficiencies preventing further analysis, 504 entities remained for further analysis (Table 1).

The majority were small enterprises $(62.6 \%)$, followed by medium-sized enterprises (19.6\%) and microbusinesses (12.1\%), with the lowest number constituting large enterprises $(5.7 \%)$. The analysed sample was dominated by enterprises from the bakery industry $(42 \%)$ and meat industry $(23 \%)$, whereas companies from the tobacco sector represented the smallest group $(0.2 \%)$ as well as those dealing with oil processing $(1.18 \%)$.

In the article of Rokicki (2011), it was shown that transport plays an important role within all 
Proceedings of the 2018 International Scientific Conference 'Economic Sciences for Agribusiness and Rural Economy' No 2, Warsaw, 7-8 June 2018, pp. 347-352

Table 1. Number of researched enterprises by sector

\begin{tabular}{|l|c|c|c|c|c|}
\hline \multirow{2}{*}{ Agribusiness sector } & \multicolumn{5}{|c|}{ Number of enterprises by size } \\
\cline { 2 - 6 } & micro & small & medium & large & total \\
\hline Meat & 9 & 59 & 38 & 11 & 117 \\
\hline Fruit and vegetable & 2 & 18 & 11 & 2 & 33 \\
\hline Oil & 0 & 5 & 1 & 0 & 6 \\
\hline Milk & 2 & 8 & 8 & 6 & 24 \\
\hline Cereals & 13 & 15 & 7 & 2 & 37 \\
\hline Bakery industry & 25 & 164 & 24 & 1 & 214 \\
\hline Other food industry & 5 & 29 & 5 & 6 & 45 \\
\hline Fodder & 2 & 11 & 1 & 0 & 14 \\
\hline Beverage producers & 3 & 6 & 4 & 0 & 13 \\
\hline Tobacco & 0 & 0 & 0 & 1 & 1 \\
\hline Total & 61 & 315 & 99 & 29 & 504 \\
\hline
\end{tabular}

Source: results of own research.

production enterprises. An appropriate transport policy may contribute to a reduction in the enterprise's costs of logistics. No research is available covering logistic solutions, including those related to transport, applied by agribusiness enterprises. The majority of enterprises did not have a separate department dealing with transport (Fig. 1). The best situation was observed in the dairy industry, where $67 \%$ of companies had a transport department, whereas the worst situation was observed in the fodder and bakery industries (21 and 23\% entities, respectively).
In the work of Górecka and Rokicki (2014), further regularities regarding transport were demonstrated. Agribusiness companies mainly used their own transport, or a combination of own and third party transport. Only $8 \%$ of entities used third party transport only. Differences were found between particular sectors. The highest number of companies using only own means of transport was found in the bakery industry ( $76 \%$ entities). If enterprises used transport services at all, these were mainly services of individual carriers, and less frequently - forwarding

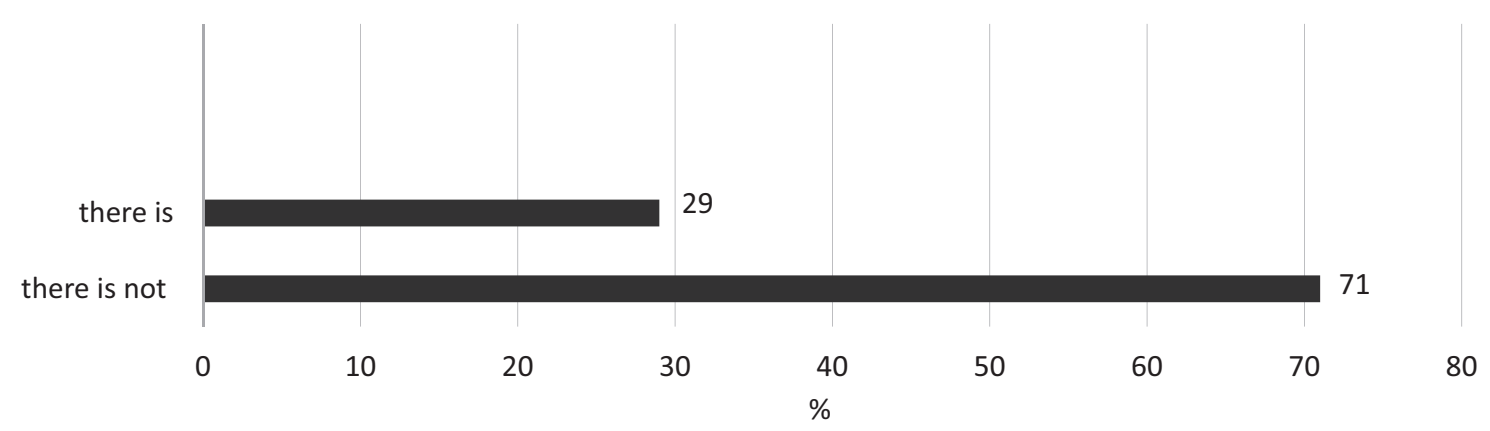

Figure 1. Existence of a separate department dealing with transport in agribusiness firms

Source: results of own research. 
services. The perception of transport management by agribusiness enterprises against the background of the competition is similar. Most enterprises considered themselves similar in this respect to the industry average. Enterprises more frequently planned to purchase own means of transport than to outsource transport services. The purchase of new vehicles in the future was mostly planned in the dairy industry $(75 \%)$, whereas outsourcing of transport services - in the oil industry $(33 \%)$.

Rokicki and Wicki (2011a) identified solutions supporting logistics processes in grain processing enterprises. In the transport field, most enterprises transported goods by their own means. Only one company, constituting a medium-sized company with regard to employment, used only external transportation. Large enterprises mainly used their own transport. Apart from own transportation, small and micro enterprises also combined their own and external transport means. Forwarding services were used to a small extent in the shipping process organisation. Typically, businesses preferred own transportation (without transport services $51 \%$ ), or just the provision of transport services alone.

In the next paper, solutions used in logistics systems in milk processing companies were compared (Wicki and Rokicki, 2011). The authors claimed that particular areas of logistics have been assessed differently. The highest assessment was given to applied solutions in the stock and transport management area. The lowest assessment was given to information management and utilization of IT solutions. Rokicki (2012a) presents the results of research on the organisation of logistics in meat processing companies. Few companies had a separate department dealing with logistics management. Transport and storage were most frequently supported logistically. Few companies in this industry also declared the use of one comprehensive IT system supporting logistics. The presented data show that, in the researched companies, logistics activities were not of considerable importance. The aim of the next article (Rokicki and Wicki, 2011b) was to evaluate the organisation of procurement and logistics costs in food processing firms. The average logistics costs amounted to $8.1 \%$ of total costs and depended significantly on the size of business or the type of processing industry. Business plans were mainly related to investment in the development of own storage facilities and transport. The aim of Klepacki's and Rokicki's (2011) article was to evaluate the level of logistics in fruit and vegetable processing firms. Research shows that the degree of logistics organisation was low. Enterprises used various means of transport in the transport of finished products. To the greatest extent firms made use of foreign transport solely (27\%) and own transport solely $(25 \%)$.

In the next article Rokicki (2012b) presents the relationship between the scale of operations and logistics solutions used in agribusiness enterprises. Research confirms the great influence of scale on the organisation of logistics, stock management methods, the choice of means of transport and methods of information flow in agribusiness companies. Small enterprises mainly based on their own means of transport. The larger the company, the more often it used external transport. There was a relationship between the scale of operation and the use of comprehensive transport services of shippers $\left(\chi_{\text {emp. }}^{2}=45.01, \chi_{0.05}^{2}=7.82\right.$, p-value $=0.000$, $\mathrm{df}=3$ ). A similar strong dependency existed when using the services of individual carriers. Rokicki (2013) presents the results of research on the organisation of transport in agribusiness companies. This article presents the relationship between the scale of operations, agribusiness sector and transport organisation in enterprises. The enterprises surveyed mainly used their own transport or a combination of own and third party transport. Use of third party transport services alone was not a frequent choice. If such services were used at all, they related mainly to transportation and less frequently to forwarding. A high differentiation between particular industries was found. Research confirms the great influence of scale of operation on the organisation of transport. In the following years after the end of project, the subject of transport in agribusiness was discussed less frequently.

The subject of transport in agribusiness was discussed by researchers from other countries. Holl (2004), in his paper, explored the role of transport in the spatial organisation of food processing firms in 
Spain. Empirical evidence from interviews suggests that, with modern logistic strategies, transport is becoming more important. Huang (2011) presented the future of Chinese agriculture in vertical integration. Then, low transport costs in the supply processing of food will be possible. Caixeta Filho (2008) discussed the shape of the Brazilian transportation system as a crucial sector for the competitive success of the entire agricultural sector. Main factors influencing agricultural road transport were type of cargo, seasonality and regional peculiarities. Alvim, de Oliveira and da Silveira (2011) proved that the transport system in Brazil was inefficient. The increase in soy production caused problems and, as a result, increased transport costs. High transportation costs were one of the problems, among others, faced by agribusiness (Oliver, ed., 2003). Stanković (2014) suggested, if transport costs are very high, agricultural firms will choose to integrate with companies that are located in their immediate vicinity. Companies then use external transport. In small and medium enterprises, the level of utilization of transportation means is significantly higher than in large enterprises, since the entrepreneur is constantly looking for new businesses to activate existing equipment (Maletić and Ceranić, 2010).

\section{CONCLUSIONS}

The article presents an overview of the most important research on transport in agribusiness carried out at the Faculty of Economic Sciences at WULSSGGW in Warsaw. The subject has been discussed more intensively with the creation of logistics studies at the Faculty. A large intensification of research and analysis was related to obtaining a large research grant by the Faculty. At that time, many studies were made by the Faculty's employees. They referred to the uncharted logistics area, including transport in agribusiness. The research allowed to determine regularities related to transport depending on the scale of operation, sector and many other aspects. The majority of enterprises did not have a separate department dealing with transport. The highest number of companies using own means of transport alone was found in the bakery industry. Large enter- prises mainly used their own transport. Apart from own transportation, small and micro enterprises also combined their own and external transport means. Forwarding services were used to a small extent in the shipping process organisation. When comparing the results of the research of employees of the Departments of Economic Sciences at WULS-SGGW with other studies, it was concluded that results were quite similar. However, the author did not find such detailed research concerning a large population of agribusiness companies in other countries. There is a need to submit applications for further studies of transport in agribusiness.

\section{REFERENCES}

1. Alvim, A.M., de Oliveira, A.L.R., da Silveira, J.M.F.J. (2011). A New Dilemma for Brazilian Agribusiness: improve logistic or face regulatory demands from biotechnology? In: Proceedings of 39th Encontro Nacional de Economia. ANPEC 2011, Brasil.

2. Baran, J., Maciejczak, M., Pietrzak, M., Rokicki, T., Wicki, L. (2008). Logistyka. Wybrane zagadnienia [Logistics. Selected issues]. Wydawnictwo SGGW, Warszawa.

3. Caixeta Filho, J.V. (2008). The determinants of transport costs in Brazil's agribusiness. In: Proceedings of 4th Annual Meeting, Lima, 17.06.2008.

4. Coyle, J.J., Bardi, E.J., Langley Jr, C.J. (2007). Zarządzanie logistyczne [Logistics management]. PWE, Warszawa.

5. Fijałkowski, J. (2003). Transport wewnętrzny w systemach logistycznych [Internal transport in logistic systems]. Oficyna Wydawnicza Politechniki Warszawskiej, Warszawa.

6. Gorecka, A., Rokicki, T. (2014). The Significance of Transportation in Agribusiness Companies. In: Proceedings of Carpathian Logistics Congress. CLC 2013, pp. 24-30.

7. Holl, A. (2004). The role of transport in firms' spatial organisation: evidence from the Spanish food processing industry. European Planning Studies, 12 (4), pp. 537-550.

8. Huang, P.C. (2011). China's new-age small farms and their vertical integration: agribusiness or co-ops? Modern China, 37 (2), pp. 107-134.

9. Kisperska-Moroń, D., Krzyżaniak, S. (2009). Logistyka [Logistics]. Biblioteka Logistyki. Instytut Logistyki i Magazynowania, Poznań. 
10. Klepacki B., Rokicki T., 2010: Stan i perspektywy rozwoju transportu w Polsce (The situation and perspectives for development of transport in Poland]. Logistyka, 3, pp. 1-10.

11. Klepacki, B., Rokicki, T. (2008). Sytuacja przedsiębiorstw zajmujących się transportem drogowym w Polsce po integracji z Unią Europejską [The situation of enterprises dealing with road transport in Poland after integration with the European Union]. In: Starzyńska, W., Rogalski, W.J. (eds.) Logistyka szansą rozwoju miasta i regionu na przykładzie ziemi piotrkowskiej [Logistics as an opportunity for the development of the city and the region on the example of Piotrków Land] Naukowe Wydawnictwo Piotrkowski, Piotrków Trybunalski, pp. 285-286.

12. Klepacki, B., Rokicki, T. (2011). Logistyka w przedsiębiorstwach przetwórstwa owoców i warzyw [Logistics in fruit and vegetable processing enterprises]. Logistyka 3, pp. 26-29.

13. Łacny, J. (2009). Funkcjonowanie międzynarodowego transportu drogowego ładunków w gospodarce globalnej [Functioning of international road freight transport in the global economy]. Wydawnictwo Uczelniane Wyższej Szkoły Gospodarki w Bydgoszczy, Bydgoszcz.

14. Larsen, T.J. (2007). Transportation and Colorado's agribusiness industry. Colorado Departments of Agriculture. Lakewood, Colorado.

15. Lasek, L., Krasoń, K., Polański, P., Tuta, A. (2008). Centra logistyczne w aspekcie rozwoju gospodarczego regionu piotrkowskiego [Logistics centers in the aspect of the economic development of the Piotrków Trybunalski region]. In: Starzyńska, W., Rogalski, W.J. (eds.) Logistyka szansą rozwoju miasta i regionu na przykładzie ziemi piotrkowskiej [Logistics as an opportunity for the development of the city and the region on the example of Piotrków Land]. Naukowe Wydawnictwo Piotrkowski, Piotrków Trybunalski, pp. 442-443.

16. Maletić, R., Ceranić, S. (2010). Small and medium enterprises as development factor of agribusiness in Republic of Serbia. Applied Studies in Agribusiness and Commerce, 4 (3-4), pp. 45-50.

17. Oliver, R. (ed.) (2003). Development of Agribusiness Enterprises. Report of the APO Seminar on Development of Agribusiness Enterprises. Asian Productivity organisation, Tokyo.
18. Rokicki, T. (2011). Transport policy at enterprises of the agribusiness sector. Annales of The Polish Association of Agricultural and Agribusiness Economists, 13 (6), pp. 211-216.

19. Rokicki, T. (2012a). Organizacja logistyki w przedsiębiorstwach przemysłu mięsnego [organisation of logistics in meat industry enterprises]. Logistyka, 2, CD 2, pp. 971-982.

20. Rokicki, T. (2012b). Skala działania a stosowane rozwiązania logistyczne w agrobiznesie [The scale of operations and logistics solutions used in agribusiness]. Logistyka, 4, CD 2, pp. 1224-1232.

21. Rokicki, T. (2013). Organizacja transportu w przedsiębiorstwach agrobiznesu (organisation of the transport in agribusiness companies), Wybrane zagadnienia logistyki stosowanej. T.2, red. J. Feliks, M. Karkula, Wydawnictwa AGH, Kraków, pp. 309-322.

22. Rokicki, T., Wicki, L. (2010). Transport i magazynowanie $\mathrm{w}$ rolnictwie jako element logistyki [Transport and storage in agriculture as an element of logistics]. Wieś Jutra, 1, pp. 41-42.

23. Rokicki, T., Wicki, L. (2011a). The scope of the use of solutions to support logistics processes in the cereals processing companies. In: Jałowiecki, P., Arkadiusz Orłowski, A. (eds.) Information systems in management $\mathrm{X}$ : computer aided logistics. Wydawnictwo SGGW, Warszawa, pp. 86-95.

24. Rokicki, T., Wicki, L. (2011b). Organizacja zaopatrzenia i koszty działań logistycznych w przedsiębiorstwach agrobiznesu. Prace Naukowe Uniwersytetu Ekonomicznego we Wrocławiu, Ekonomia, 166, pp. 634-646.

25. Rydzkowski, W., Wojewódzka-Król, K. (2009). Transport. Problemy transportu w rozszerzonej UE [Transport. Transport problems in the enlarged EU]. Wydawnictwo Naukowe PWN, Warszawa.

26. Stanković, M. (2018). Agricultural franchising and contribution to achieving objectives of the EU common agricultural policy. Economics of Agriculture, 61 (4), pp. 1021-1035.

27. Wicki, L., Rokicki, T. (2011). Differentiation of level of logistics activities in milk processing companies, Information systems in management X: computer aided logistics In: Jałowiecki, P., Arkadiusz Orłowski, A. (eds.) Information systems in management X: computer aided logistics. Wydawnictwo SGGW, Warszawa, pp. 117-127. 